\title{
Does Friendship Matter? \\ Sharing, Fairness and Parochial Altruism in African Children and Adolescents
}

\section{Marina L. Butovskaya}

Institute of Ethnology and Anthropology, Russian Academy of Sciences, Moscow; National Research University Higher School of Economics, Moscow; Russian State University for the Humanities, Moscow

\section{Valentina N. Burkova}

Institute of Ethnology and Anthropology, Russian Academy of Sciences, Moscow; National Research University Higher School of Economics, Moscow

\section{Dmitriy V. Karelin}

Institute of Geography, Russian Academy of Sciences, Moscow

\begin{abstract}
In this paper we present data on the altruistic behavior among rural Meru and urban mixed-ethnic children of Dar-es-Salaam of Tanzania, based on their decision-making in three sets of sharing games. Particularly, we examine the readiness of rural and urban African schoolchildren to take prosocial, sharing and fairness decisions; we also reveal to what extent these decisions are congruent towards friends and anonymous peers and test the gender differences in the decision-making. Our results provide another confirmation of the parochial altruism hypothesis.
\end{abstract}




\section{INTRODUCTION}

Social norms and the associated altruistic behaviors are decisive for the evolution of human cooperation and the maintenance of social order (Boyd et al. 2003; Elster 1989; Gintis 2000; Fehr and Gachter 2002; Nowak and Sigmund 2005; Bernhard et al. 2006). But, altruistic norms often arise in the context of intergroup conflicts under the influence of the parochialism - a preference for favoring the members of one's ethnic, racial or language group (Bornstein 2003; Bernhard et al. 2006; Fehr et al. 2008; Fehr et al. 2013). Parochialism plays a significant role in decision-making process. People tend to reward in-group members more than outgroup members (Tajfel et al. 1971). Studies show that people are more altruistic toward friends than to strangers (Brañas-Garza et al. 2012). As demonstrated by meta-analysis, conducted by Balliet with co-authors (Balliet et al. 2014), in dictator games people prefer to give more to in-group members compared to outgroup ones (Ben-Ner et al. 2009; Liebe and Tutic 2010; Whitt and Wilson 2007). However, other studies found no evidence for such intergroup discrimination (Lei and Vesely 2010; Stürmer et al. 2006). Apparently, parochialism promotes the functioning and effectiveness of the own group, as such behavior in perspective gives people long-term benefits and increases the chances for survival (Balliet et al. 2014).

Besides, ethnographic evidence suggests that there is a strong role of egalitarian 'instincts' in human evolutionary history (Boehm 1997; Fehr et al. 2008). For example, food sharing, cooperative hunting and participation in warfare seems to be the social norms rather than the exception in small-scale societies, and egalitarian sentiments play a part in contemporary large-scale societies as well (Boehm et al. 1993; Sober and Wilson 1999; Kaplan and Gurven 2005; Bernhard et al. 2006; Dawes et al. 2007; Fowler et al. 2005; Fehr et al. 2008).

The simultaneous development of altruistic behavior and parochialism and the gender differences in parochialism are also considered in the framework of evolutionary theory (Choi and Bowles 2007). According to the theory, the driving force behind evolutionary process is frequent intergroup conflicts. Since mainly males were involved in intergroup fights, it seems possible that evolution favored a gender bias in parochialism (Fehr et al. 2008). Males bore the main cost of intergroup conflict in terms of injuries and deaths and often gained more than females in the case of victory because of the increase in the pool of potential mating partners (Chagnon 1988; Fehr et al. 2008). Females are more frequently described as a more egalitarian and less 
frequently altruistic than males in adulthood (Croson and Gneezy 2009), and in children and adolescents (Fehr et al. 2013).

Fehr et al. (2008) found that 3-8 years old boys showed a much stronger in-group bias than girls in the envy game. In the process of socialization, children acquire certain social norms and rules, which are expressed in an increasingly egalitarian behavior at the age of 38 years (Eisenberg and Mussen 1989; Fehr et al. 2008). Children become more sensitive about the opinions of others about themselves, and at an older age they take care of how their behavior is embedded in general accepted norms and what benefit or harm may entail (Eisenberg and Mussen 1989; Choi and Bowles 2007; Fehr et al. 2008). A strong decrease in spitefulness was found among the children from 8 to 17 years old; besides, egalitarianism becomes less frequent and altruism - more prominent with age, while, parochialism significantly arises in the teenage years (Fehr et al. 2013).

The earlier findings suggested that the ability to take the other's perspective may account for developmental differences in prosocial behavior (Güroğlu et al. 2014). Experimental studies with children of 3-4 years old reveal the links between theory of mind skills and future-oriented prosocial behavior: children had to make choice between immediate and delayed sticker rewards (these rewards accrued either to self, to a play partner, or were shared), and there were also presented with standard theory of mind tasks (assessing the understanding of belief and desire and executive function task and in which the children had to inhibit pointing to a baited box in order to win the cookie within) (Moore et al. 1998). Results indicate than children's ability to show future-oriented prosocial or sharing behavior is linked developmentally both to the ability to image conflicting mental states and the ability to inhibit responding to salient events (Moore et al. 1998). The "“otherorientation" is tapped by the cognitive ability to take others' perspectives and incorporate these perspectives into decision-making, which continues to develop into late adolescence' (Dumontheil et al. 2010). 'The differential patterns of behavior for interaction partners suggest the special role of friendships as forming the most significant developmental contexts across adolescence (Hartup 1996; cited in Güroğlu et al. 2014), especially for prosocial behavior (Carlo et al. 1999).

The goals of this paper are to test the readiness of rural and urban African schoolchildren to take prosocial, sharing and fairness decisions; to reveal to what extent these decisions are congruent toward friends and anonymous peers, and to consider the gender differences in decision-making. 
The hypotheses to be tested are the following:

1. Decision-making in children and adolescents will be driven by parochialism, and this tendency tends to increase with age;

2. Rural and urban children will probably be different in their decision-making in a way that urban children will be more collectivistic and ready to share with anonymous peers, while rural ones will be more friend-oriented;

3. Urban children will be more oriented towards fairness than rural ones;

4. Males will be more parochial in sharing, compared to females;

5. The patterns of correlations between decision-making in all the three games and self-ratings on helping relatives will be different for males and females.

\section{METHODS}

\section{Subjects}

The data for this study were collected in 2015-2016 and 2018 in the United Republic of Tanzania. The total sample comprised 372 children and adolescents, from rural and urban areas. The rural sample has been represented by the Meru ethnicity (283 total: 139 boys and 134 girls) and urban children of mix-ethnic origin from Dar-es-Salaam ( 89 total: 68 boys and 21 girls) with a mean age of 14.87 years, and a range from 8 to 19 years. All participants completed a demographic questionnaire to reveal their age, sex, and ethnicity.

The Meru (Wameru, Rwa, Rwo, and Warvo) of Tanzania is one of the ethnic groups involved in intensive agriculture and now living in the south-eastern and eastern slopes of Mount Meru. Among the Meru 94 per cent of population are Christians $(75$ per cent protestants, 25 per cent - Catholics), and 3 per cent are adherents of Islam. Anthropologically Meru are metis population, formed by the mixing of Eastern Bantu and Maasai tribes (Butovskaya et al. 2016). Traditionally Meru was a typical example of a patriarchal, patrilocal, and clan-organized society (Butovskaya et al. 2016; Lerner 1986).

Urban sample from Dar-es-Salaam was highly mixed, consisting of representatives of 28 different ethnics, including Hehe, Gogo, Zaramo, Chagga, Pare and Sukuma. Dar-es-Salaam is the economic capital of Tanzania and currently is one of the fastest growing cities in the world, attracting crowds of newcomers from rural regions, searching for better life. 


\section{Experimental design and procedure}

Children's prosocial orientations were evaluated applying experimental method, originally developed by Fehr with co-authors (Fehr et al. 2008). At the beginning, each participant was instructed about the rules of each of the three games, so that we could make sure that a child completely understood the experiment and the consequences of different choices. In all the games a player had to make decisions about allocation units of candies to himself/herself and/or to the partner. Every child played the Prosocial game, the Envy game and the Sharing game with imagined partners. Thus, the three dilemmas were suggested:

1) Prosocial game: a player has to decide, whether to take a candy for himself, but give nothing to a potential reviewer, or to take one candy for himself and give one candy to another child. In this setting, willingness to do good for another person, with no cost for oneself has been tested. 'This game serves as a measure of the basic form of prosociality, namely the willingness to avoid advantageous inequality for the benefit of the partner' (Fehr et al. 2013). As mentioned before by Fehr and his co-authors, such design suggests no costs for the decision-maker, but different motives may drive the allocation $1: 1$, including egalitarianism, and desire to avoid inequality, efficiency seeking, and even self-interested behavior, with the random choice of allocation decisions in direction of recipient (Fehr and Schmidt 1999; Charness and Rabin 2002; Fehr et al. 2013).

2) Envy game: a participant obtains one candy for himself, but can choose how many candies will be provided to another child: nothing, one or two. In this setting we test for jealousy. As in the prosocial game, the decision-maker can increase the partner's payoff at no cost to himself/herself, but in the current case, such choice may result in disadvantageous inequality.

3) Sharing game: a player has to make a choice related to the real cost: he/she is suggested either to take two candies for himself/herself, or to share with other child (to give one or two candies). In this case we tested the altruistic motivations of a player. Contrary to previous games, the egalitarian choice here $(1: 1)$ is costly to the player, and may be interpreted as inequality aversion, thus indicating prosocial behavior, while $(0: 2)$ choice is even more costly and may be driven by purely altruistic motives.

The order of the presentation of games was randomized. Each participant had been enrolled for two series of such tasks: in the first series a player had been told that the receiver was one of his/her friends (from the same class), in the second - a stranger fellow of the same 
age. We also made it clear to the children that neither other children nor their parents/teachers would be informed about their decisions.

All subjects were later classified according to their decisions in three games into five behavioral types, following the classification presented originally by Fehr with co-authors (Fehr et al. 2013) with some modifications: strongly egalitarian subjects (those, preferring the egalitarian allocation (1:1) in all three games); weakly egalitarian subjects (choosing the egalitarian allocation in all games, except the sharing game, in which egalitarian behavior is costly); strongly altruistic subjects (those players who always select the allocation that maximizes the partner's benefits, which costs to his/her own interests); medium altruistic subjects (maximizes the partner's payoff and at the same time the joint payoff); weakly altruistic subjects, choosing the allocation that maximizes the partner's payoff and the joint payoff in all games except the sharing game; highly spiteful subjects, that always prefer the allocation that minimizes the partner's payoff plus maximizes the positive difference in own versus partner's payoff; weakly spiteful, that always prefer the allocation that minimizes the partner's payoff or maximizes the positive difference in own versus partner's payoff (see Table 1).

Definitions of behavioral types of decision-makers, Table 1 based on allocations in all three games

\begin{tabular}{|l|c|c|c|}
\hline \multicolumn{1}{|c|}{ Type } & $\begin{array}{c}\text { Prosocial } \\
\text { game }\end{array}$ & $\begin{array}{c}\text { Envy } \\
\text { (fairness) game }\end{array}$ & $\begin{array}{c}\text { Sharing } \\
\text { game }\end{array}$ \\
\hline Highly egalitarian & $(1: 1)$ & $(1: 1)$ & $(1: 1)$ \\
\hline Weakly egalitarian & $(1: 1)$ & $(1: 1)$ & $(2: 0)$ \\
\hline Highly altruistic & $(1: 1)$ & $(1: 2)$ & $(0: 2)$ \\
\hline Medium altruistic & $(1: 1)$ & $(1: 2)$ & $(1: 1)$ \\
\hline Weakly altruistic & $(1: 1)$ & $(1: 2)$ & $(2: 0)$ \\
\hline Highly spiteful & $(1: 0)$ & $(1: 0)$ & $(2: 0)$ \\
\hline Weakly spiteful & $(1: 0)$ & $(1: 0)$ & $(1: 1)$ \\
\hline
\end{tabular}

\section{RESULTS}

Differences in results obtained for prosocial, fairness and sharing games with friends and unknown partners for the whole sample

We conducted a set of Chi-Square tests, using Cross-tabs statistics to reveal the differences in readiness for prosocial behavior, fairness and sharing towards friends and anonymous peers for the whole sam- 
ple. Children were more ready to behave prosocially towards friends, than towards anonymous peers (Chi-square $=11.797 ; \mathrm{p}=0.001 ; \mathrm{df}=1$; $\mathrm{n}=322$ ) (see Fig. 1a, b).

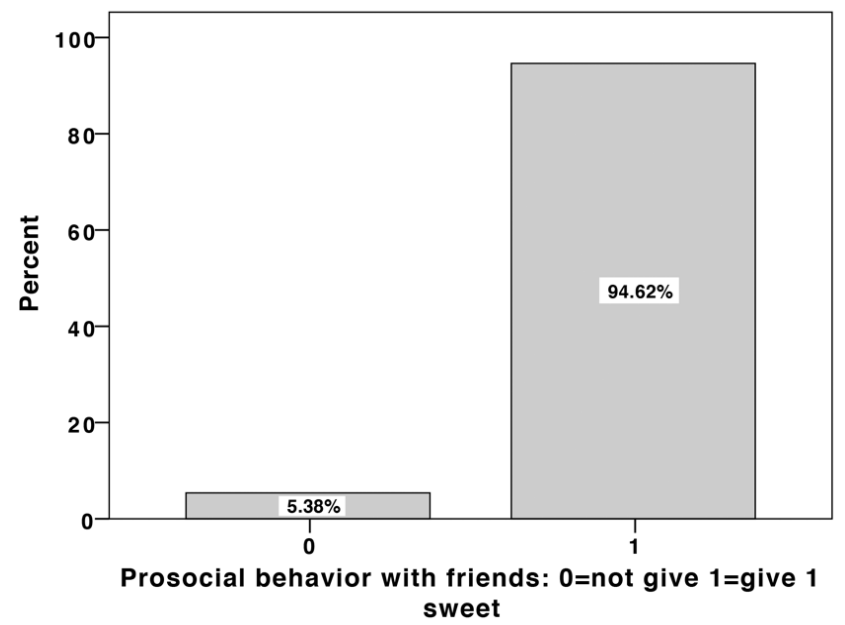

Fig. 1a. Prosocial behavior with friends

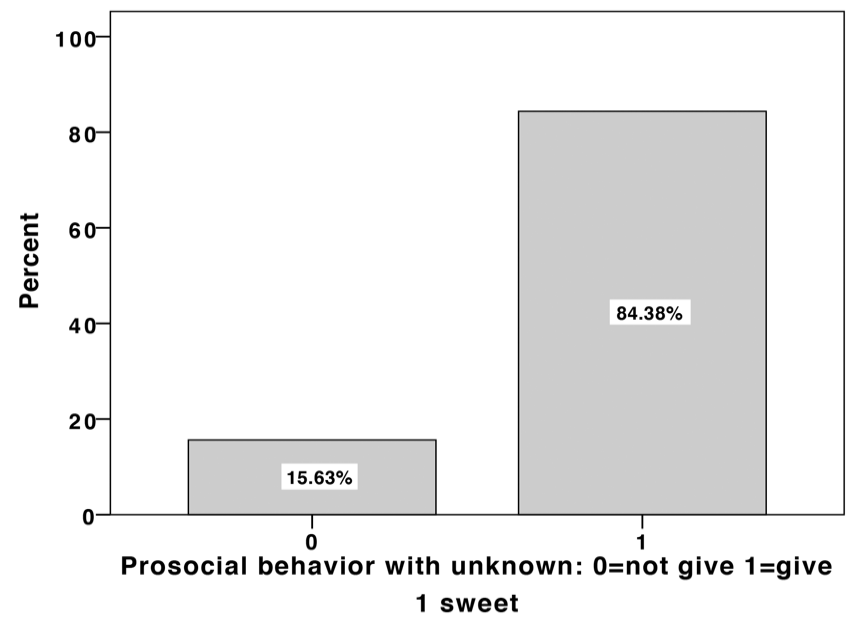

Fig. 1b. Prosocial behavior with anonymous peers

In the fairness game, children significantly differed in decisions on candies allocation towards friends and unknown recipients (Chi-square $=$ $=44.145 ; \mathrm{p}=0.0001 ; \mathrm{df}=4 ; \mathrm{n}=322) .61 .19$ per cent of participants followed the fairness principles and provided the same amount of can- 
dies (one) to their friends, and about one-third of them (33.43 per cent) were even ready to give to their friends more candies than they obtained (see Fig. 2a, b). This means that friendship feelings provide certain degree of tolerance if friends obtain higher amount of resources. 68.47 per cent of individuals demonstrated fairness in candies allocation towards unknown peers and 24.15 per cent of participants donated even more, than they received themselves (see Fig. 2b). The participants decisions for sweets allocation towards friends and anonymous peers in this type of game were positive correlated (Spearman's rho $=0.301 ; \mathrm{p}=0.0001 ; \mathrm{n}=352$ ).

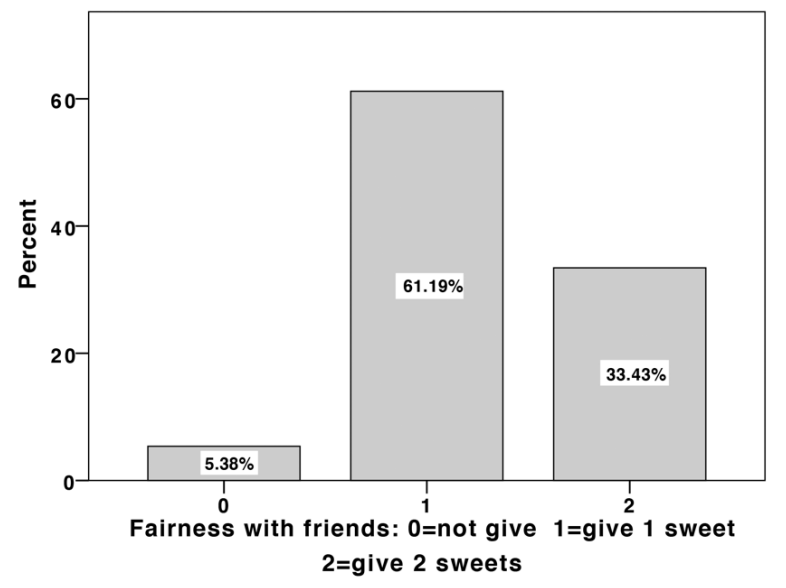

Fig. 2a. Fairness in distribution of candies towards friends

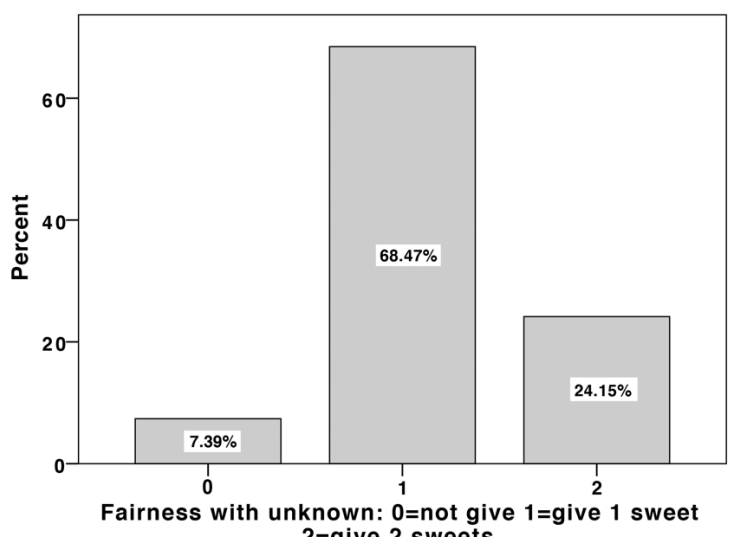

Fig. 2b. Fairness in distribution of candies towards anonymous peers 
Children were discriminant in sharing towards friends and nonfriends in sharing game, and were more ready to share with friends (Chi-Square $=45.802 ; \mathrm{p}=0.0001 ; \mathrm{df}=4 ; \mathrm{n}=322$ ). However, the majority of those, who shared with friends, also shared with unknown peers. 10.25 per cent of our sample did not share with friends, and 17.29 per cent did not share with an unknown child (see Fig. 3a, b).

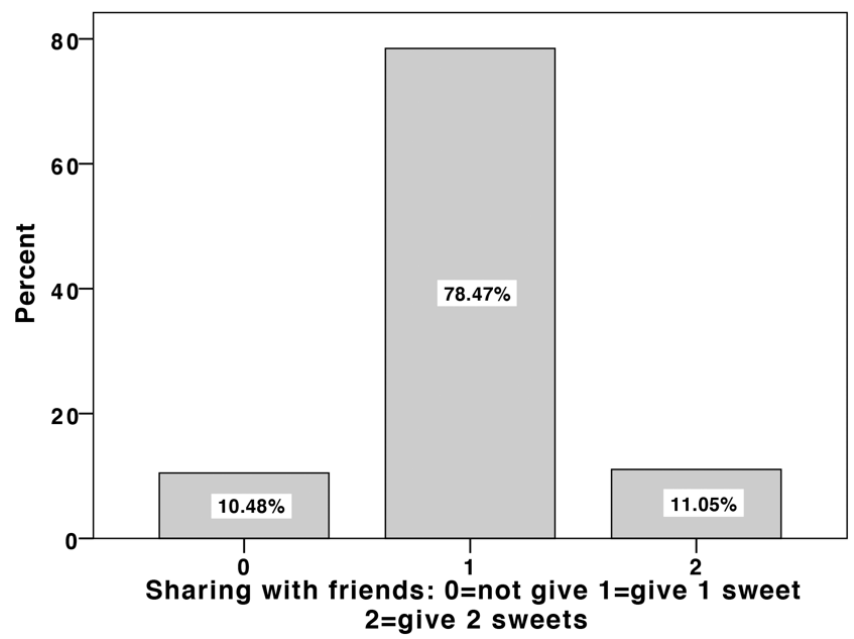

Fig. 3a. Sharing with friends

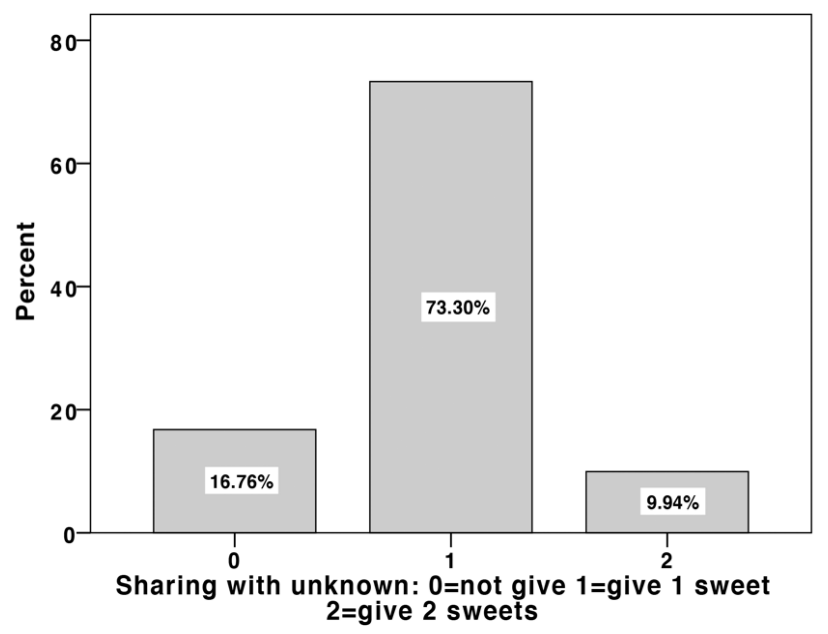

Fig. 3b. Sharing with anonymous peers 


\section{Game decisions and readiness to help relatives}

Cross-tabulations were conducted to test possible associations in game decisions and self-ratings on helping relatives. No associations between prosociality towards friends and helping towards relatives were found (Chi-Square $=1.294 ; \mathrm{p}=0.862 ; \mathrm{df}=8$ ), but in the case of prosociality towards anonymous peers and helping relatives the association was significant (Chi-Square $=15.376 ; \mathrm{p}=0.004 ; \mathrm{df}=8$ ).

Independent of whether individuals were inclined to help relatives or not, they were following fairness principles both in the case of friends and anonymous peers. Their decisions were different for situations with friends and unknown peers. We did not find any correlation between self-ratings on helping relatives and fairness decisions in relation to friends (Chi-Square $=3.901 ; \mathrm{p}=0.866 ; \mathrm{df}=8$ ) (see Fig. $4 \mathrm{a}$ ), but obtained significant positive correlation between helping relatives and fairness towards anonymous peers (Chi-Square $=19.958 ; \mathrm{p}=0.001$; $\mathrm{df}=8$ ) (see Fig. $4 \mathrm{~b}$ ).

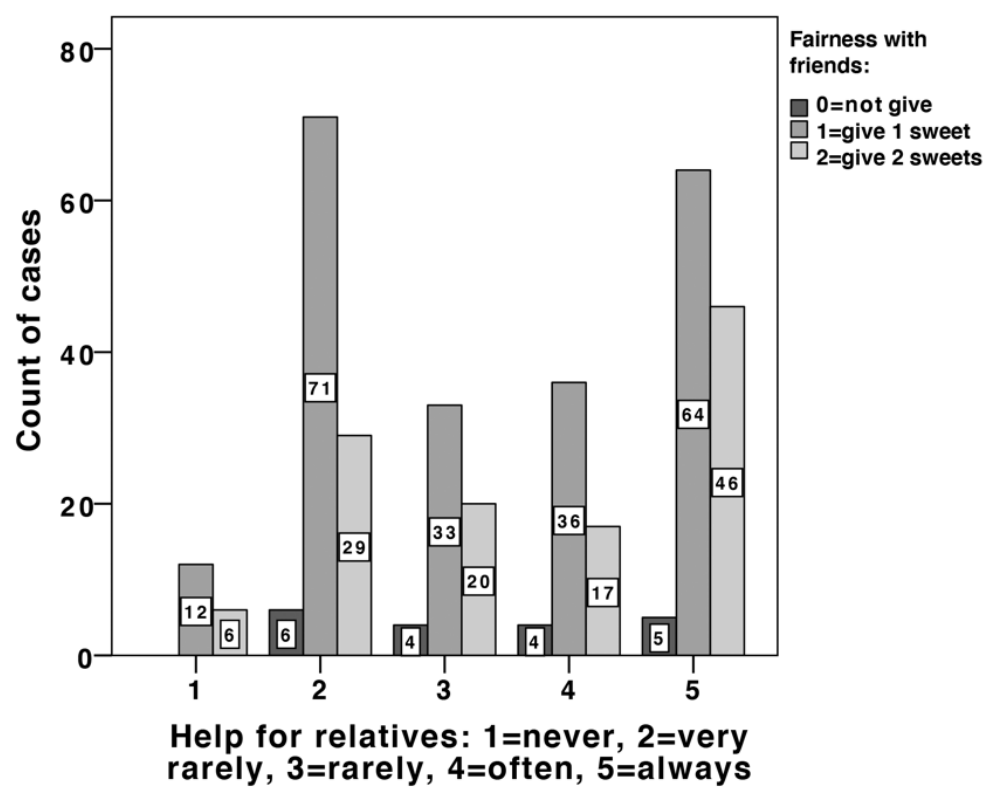

Fig. 4a. The association between readiness to help relatives and fairness towards friends 


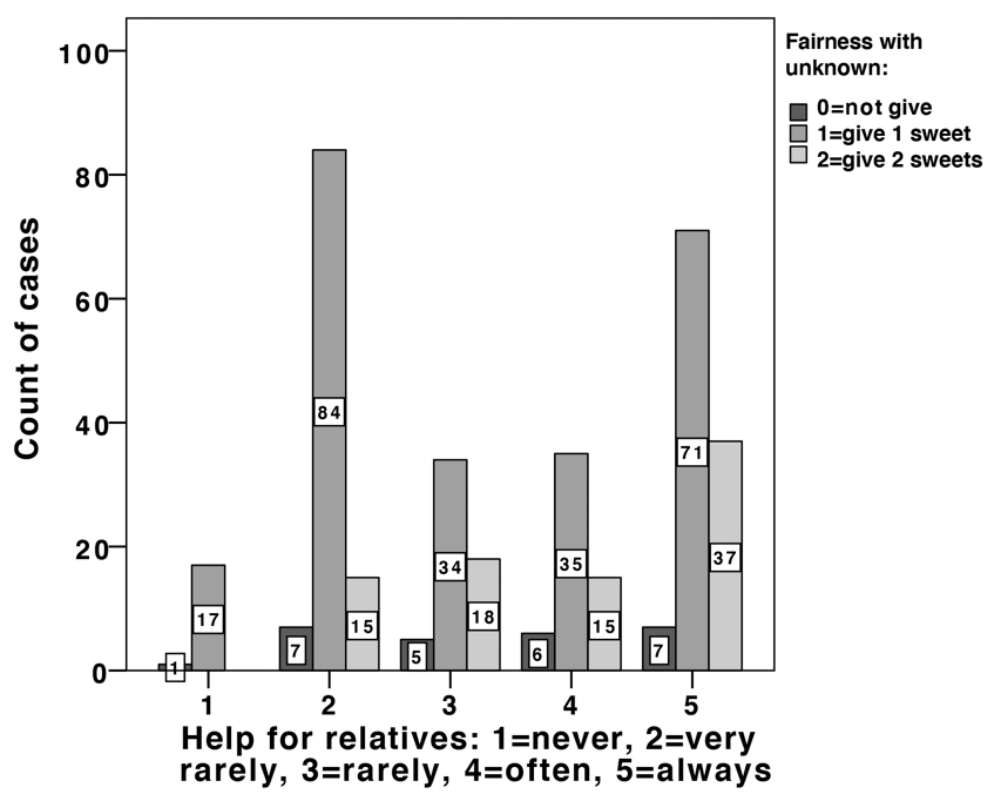

Fig. 4b. The association between readiness to help relatives and fairness towards anonymous peers

We tested the correlation between readiness to help relatives and sharing decisions with respect to friends, and found that those children who were inclined to help relatives were also more likely to share with friends $($ Chi-Square $=16.554 ; \mathrm{p}=0.035 ; \mathrm{df}=8)$. The same was true in the case of sharing with anonymous peers (Chi-Square $=21.704$; $\mathrm{p}=0.005 ; \mathrm{df}=8$ ).

We conducted non-parametric correlation analysis to test if inclinations to help relatives are associated with game decisions in total sample (see Table 2a, b). It was found that boys, who were rating themselves higher on helping relatives, played more altruistically in all three games with an unknown child (see Table 2a). Girls who were helping relatives were also ready to give more sweets in fairness situation with an unknown child, as well as play more costly with friends (see Table 2b). 
Correlation between game decisions and desire to help relatives (boys)

\begin{tabular}{|c|c|c|c|c|c|c|c|}
\hline & \begin{tabular}{|c|} 
Pro- \\
social \\
behavior \\
with \\
friends
\end{tabular} & $\begin{array}{c}\text { Pro- } \\
\text { social } \\
\text { behavior } \\
\text { with } \\
\text { anony- } \\
\text { mous } \\
\text { peers }\end{array}$ & $\begin{array}{c}\text { Fairness } \\
\text { in dis- } \\
\text { tribu- } \\
\text { tion of } \\
\text { sweets } \\
\text { towards } \\
\text { friends }\end{array}$ & \begin{tabular}{|c|} 
Fairness \\
in distri- \\
bution \\
of sweets \\
towards \\
anonymo- \\
us peers
\end{tabular} & \begin{tabular}{|c|} 
Sharing \\
with \\
friends
\end{tabular} & $\begin{array}{c}\text { Sharing } \\
\text { with } \\
\text { anony- } \\
\text { mous } \\
\text { peers }\end{array}$ & $\begin{array}{l}\text { Help } \\
\text { for } \\
\text { rela- } \\
\text { tives }\end{array}$ \\
\hline $\begin{array}{l}\text { Prosocial } \\
\text { behavior } \\
\text { with friends }\end{array}$ & $-\mathrm{X}$ & NS & NS & NS & $\mathrm{NS}$ & $\begin{array}{l}\mathrm{r}=.177^{*} \\
\mathrm{p}=.014 \\
\mathrm{~N}=191\end{array}$ & $\mathrm{NS}$ \\
\hline $\begin{array}{l}\text { Prosocial } \\
\text { behavior } \\
\text { with anon- } \\
\text { ymous } \\
\text { peers }\end{array}$ & NS & - & NS & $\begin{array}{l}r=.154^{*} \\
p=.034 \\
N=191\end{array}$ & $\begin{array}{l}\mathrm{r}=.190 \\
\mathrm{p}=.009 \\
\mathrm{~N}=191\end{array}$ & $\begin{array}{l}\mathrm{r}=.348^{* *} \\
\mathrm{p}=.000 \\
\mathrm{~N}=191\end{array}$ & $\begin{array}{l}\mathrm{r}=.240^{* *} \\
\mathrm{p}=.001 \\
\mathrm{~N}=191\end{array}$ \\
\hline $\begin{array}{l}\text { Fairness in } \\
\text { distribution } \\
\text { of sweets } \\
\text { towards } \\
\text { friends }\end{array}$ & NS & NS & - & $\begin{array}{l}\mathrm{r}=.217^{* *} \\
\mathrm{p}=.003 \\
\mathrm{~N}=191\end{array}$ & NS & NS & NS \\
\hline $\begin{array}{l}\text { Fairness in } \\
\text { distribution } \\
\text { of sweets } \\
\text { towards } \\
\text { anonymous } \\
\text { peers }\end{array}$ & $\mathrm{NS}$ & $\begin{array}{l}r=.154^{*} \\
p=.034 \\
N=191\end{array}$ & $\begin{array}{l}\mathrm{r}=.217^{* *} \\
\mathrm{p}=.003 \\
\mathrm{~N}=191\end{array}$ & - & NS & NS & $\begin{array}{l}\mathrm{r}=.195^{* *} \\
\mathrm{p}=.007 \\
\mathrm{~N}=191\end{array}$ \\
\hline $\begin{array}{l}\text { Sharing } \\
\text { with friends }\end{array}$ & NS & $\begin{array}{l}\mathrm{r}=.190^{* *} \\
\mathrm{p}=.009 \\
\mathrm{~N}=191\end{array}$ & NS & NS & - & $\begin{array}{l}\mathrm{r}=.388^{* *} \\
\mathrm{p}=.000 \\
\mathrm{~N}=191\end{array}$ & NS \\
\hline $\begin{array}{l}\text { Sharing } \\
\text { with ano- } \\
\text { nymous } \\
\text { peers }\end{array}$ & $\begin{array}{l}r=.177^{*} \\
p=.014 \\
N=191\end{array}$ & $\begin{array}{l}\mathrm{r}=.348^{* *} \\
\mathrm{p}=.000 \\
\mathrm{~N}=191\end{array}$ & $\mathrm{NS}$ & NS & $\begin{array}{l}\mathrm{r}=.388^{* *} \\
\mathrm{p}=.000 \\
\mathrm{~N}=191\end{array}$ & - & $\begin{array}{l}\mathrm{r}=.226^{* *} \\
\mathrm{p}=.002 \\
\mathrm{~N}=191\end{array}$ \\
\hline $\begin{array}{l}\text { Help for } \\
\text { relatives }\end{array}$ & NS & $\begin{array}{l}\mathrm{r}=.240^{* *} \\
\mathrm{p}=.001 \\
\mathrm{~N}=191\end{array}$ & NS & $\begin{array}{l}\mathrm{r}=.195^{* *} \\
\mathrm{p}=.007 \\
\mathrm{~N}=191\end{array}$ & $\mathrm{NS}$ & $\begin{array}{l}\mathrm{r}=.226^{* *} \\
\mathrm{p}=.002 \\
\mathrm{~N}=191\end{array}$ & - \\
\hline
\end{tabular}

Notes: $\mathrm{NS}=$ not significant

${ }^{*}$ Correlation is significant at the 0.05 level (2-tailed).

${ }^{* *}$ Correlation is significant at the 0.01 level (2-tailed). 
Table $2 b$

Correlation between game decisions

and desire to help relatives (girls)

\begin{tabular}{|c|c|c|c|c|c|c|c|}
\hline & \begin{tabular}{|c|} 
Proso- \\
cial \\
behav- \\
ior with \\
friends
\end{tabular} & $\begin{array}{c}\text { Proso- } \\
\text { cial } \\
\text { behav- } \\
\text { ior with } \\
\text { anon- } \\
\text { ymous } \\
\text { peers }\end{array}$ & $\begin{array}{c}\text { Fairness } \\
\text { in distri- } \\
\text { bution of } \\
\text { sweets } \\
\text { towards } \\
\text { friends }\end{array}$ & $\begin{array}{c}\text { Fairness } \\
\text { in distri- } \\
\text { bution } \\
\text { of sweets } \\
\text { towards } \\
\text { anony- } \\
\text { mous } \\
\text { peers }\end{array}$ & $\begin{array}{c}\text { Shar- } \\
\text { ing } \\
\text { with } \\
\text { friends }\end{array}$ & $\begin{array}{l}\text { Sharing } \\
\text { with } \\
\text { anony- } \\
\text { mous } \\
\text { peers }\end{array}$ & $\begin{array}{l}\text { Help } \\
\text { for } \\
\text { rela- } \\
\text { tives }\end{array}$ \\
\hline $\begin{array}{l}\text { Prosocial } \\
\text { behavior } \\
\text { with } \\
\text { friends }\end{array}$ & - & $\begin{array}{l}r=.430 \\
p=.000 \\
N=161\end{array}$ & NS & NS & $\begin{array}{l}\mathrm{r}=.249^{*} \\
\mathrm{p}=.001 \\
\mathrm{~N}=161\end{array}$ & $\begin{array}{l}\mathrm{r}=.420^{* *} \\
\mathrm{p}=.000 \\
\mathrm{~N}=161\end{array}$ & $\mathrm{NS}$ \\
\hline $\begin{array}{l}\text { Prosocial } \\
\text { behavior } \\
\text { with anon- } \\
\text { ymous } \\
\text { peers }\end{array}$ & $\begin{array}{l}\mathrm{r}=.430 \\
\mathrm{p}=.000 \\
\mathrm{~N}=161\end{array}$ & - & NS & $\mathrm{NS}$ & $\begin{array}{l}\mathrm{r}=.184^{*} \\
\mathrm{p}=.019 \\
\mathrm{~N}=161\end{array}$ & $\begin{array}{l}r=.395^{* *} \\
p=.000 \\
N=161\end{array}$ & NS \\
\hline $\begin{array}{l}\text { Fairness in } \\
\text { distribu- } \\
\text { tion of } \\
\text { sweets } \\
\text { towards } \\
\text { friends } \\
\end{array}$ & NS & $\mathrm{NS}$ & - & $\begin{array}{l}\mathrm{r}=.394^{* *} \\
\mathrm{p}=.000 \\
\mathrm{~N}=161\end{array}$ & $\mathrm{NS}$ & $\begin{array}{l}\mathrm{r}=.178^{*} \\
\mathrm{p}=.023 \\
\mathrm{~N}=161\end{array}$ & $\mathrm{NS}$ \\
\hline $\begin{array}{l}\text { Fairness } \\
\text { in distribu- } \\
\text { tion of } \\
\text { sweets } \\
\text { towards } \\
\text { anonymous } \\
\text { peers }\end{array}$ & NS & NS & $\begin{array}{l}r=.394^{\text {** }} \\
\mathrm{p}=.000 \\
\mathrm{~N}=161\end{array}$ & - & $\mathrm{NS}$ & NS & $\begin{array}{l}\mathrm{r}=.166^{*} \\
\mathrm{p}=.035 \\
\mathrm{~N}=161\end{array}$ \\
\hline $\begin{array}{l}\text { Sharing } \\
\text { with } \\
\text { friends }\end{array}$ & $\begin{array}{l}\mathrm{r}=.249^{* *} \\
\mathrm{p}=.001 \\
\mathrm{~N}=161\end{array}$ & $\begin{array}{l}\mathrm{r}=.184^{*} \\
\mathrm{p}=.019 \\
\mathrm{~N}=161\end{array}$ & NS & NS & - & $\begin{array}{l}r=.176^{* *} \\
p=.025 \\
N=161\end{array}$ & $\begin{array}{l}\mathrm{r}=.165^{*} \\
\mathrm{p}=.037 \\
\mathrm{~N}=161\end{array}$ \\
\hline $\begin{array}{l}\text { Sharing } \\
\text { with anon- } \\
\text { ymous } \\
\text { peers } \\
\end{array}$ & $\begin{array}{l}\mathrm{r}=.420 \\
\mathrm{p}=.000 \\
\mathrm{~N}=161\end{array}$ & $\begin{array}{l}\mathrm{r}=.395^{* *} \\
\mathrm{p}=.000 \\
\mathrm{~N}=161\end{array}$ & $\begin{array}{l}\mathrm{r}=.178^{* *} \\
\mathrm{p}=.023 \\
\mathrm{~N}=161\end{array}$ & $\mathrm{NS}$ & $\begin{array}{l}\mathrm{r}=.176 \\
\mathrm{p}=.025 \\
\mathrm{~N}=161\end{array}$ & - & $\mathrm{NS}$ \\
\hline $\begin{array}{l}\text { Help for } \\
\text { relatives }\end{array}$ & $\mathrm{NS}$ & NS & $\mathrm{NS}$ & $\begin{array}{l}\mathrm{r}=.166^{*} \\
\mathrm{p}=.035 \\
\mathrm{~N}=161\end{array}$ & $\begin{array}{l}\mathrm{r}=.165^{\circ} \\
\mathrm{p}=.037 \\
\mathrm{~N}=161\end{array}$ & $\mathrm{NS}$ & - \\
\hline
\end{tabular}

Notes: $\mathrm{NS}=$ not significant

${ }^{*}$ Correlation is significant at the 0.05 level (2-tailed).

${ }^{* *}$ Correlation is significant at the 0.01 level (2-tailed). 


\section{Differences in decision making between rural and urban children}

We tested the differences in decision-making between rural (Meru children) and urban (Dar-es-Salaam, mixed-ethnic origin) samples (see Table 3).

Table 3

Differences between rural and urban schoolchildren in prosocial, fairness and sharing games

\begin{tabular}{|c|c|c|c|c|c|c|}
\hline \multirow{2}{*}{ Games } & \multirow{2}{*}{$\begin{array}{c}\text { Condition } \\
\text { of games }\end{array}$} & \multicolumn{2}{|c|}{ Place } & \multirow{2}{*}{ Total } & \multirow{2}{*}{$\begin{array}{c}\text { Chi } \\
\text { square }\end{array}$} & \multirow[b]{2}{*}{ p } \\
\hline & & Rural & Urban & & & \\
\hline \multirow{2}{*}{$\begin{array}{l}\text { Prosocial } \\
\text { game with } \\
\text { friend }\end{array}$} & $0=$ not give sweet & $17(6 \%)$ & $2(3 \%)$ & 19 & \multirow[t]{2}{*}{1.205} & \multirow[t]{2}{*}{0.272} \\
\hline & $1=$ give 1 sweet & $264(94 \%)$ & $70(97 \%)$ & 334 & & \\
\hline \multirow{2}{*}{$\begin{array}{l}\text { Prosocial } \\
\text { game with } \\
\text { unknown } \\
\text { peers }\end{array}$} & $0=$ not give sweet & $39(14 \%)$ & $16(22 \%)$ & 55 & \multirow[t]{2}{*}{2.988} & \multirow[t]{2}{*}{0.84} \\
\hline & $1=$ give 1 sweet & $241(86 \%)$ & $56(78 \%)$ & 297 & & \\
\hline \multirow{3}{*}{$\begin{array}{l}\text { Fairness } \\
\text { game with } \\
\text { friend }\end{array}$} & $0=$ not give sweet & $19(7 \%)$ & $0(0 \%)$ & 19 & \multirow[t]{3}{*}{7.643} & \multirow[t]{3}{*}{0.022} \\
\hline & $1=$ give 1 sweet & $175(62 \%)$ & $41(57 \%)$ & 216 & & \\
\hline & $2=$ give 2 sweets & $87(31 \%)$ & $31(43 \%)$ & 118 & & \\
\hline \multirow{3}{*}{$\begin{array}{l}\text { Fairness } \\
\text { game with } \\
\text { unknown } \\
\text { peers }\end{array}$} & $0=$ not give sweet & $26(9.3 \%)$ & $0(0 \%)$ & 26 & \multirow[t]{3}{*}{23.176} & \multirow[t]{3}{*}{0.0001} \\
\hline & $1=$ give 1 sweet & $175(62.5 \%)$ & $66(92 \%)$ & 241 & & \\
\hline & $2=$ give 2 sweets & $79(28.2 \%)$ & $6(8 \%)$ & 85 & & \\
\hline \multirow{3}{*}{$\begin{array}{l}\text { Sharing } \\
\text { game with } \\
\text { friend }\end{array}$} & $0=$ not give sweet & $34(12 \%)$ & $3(4 \%)$ & 37 & \multirow[t]{3}{*}{16.909} & \multirow[t]{3}{*}{0.0001} \\
\hline & $1=$ give 1 sweet & $208(74 \%)$ & $69(96 \%)$ & 277 & & \\
\hline & $2=$ give 2 sweets & $39(14 \%)$ & $0(0 \%)$ & 39 & & \\
\hline \multirow{3}{*}{$\begin{array}{l}\text { Sharing } \\
\text { game with } \\
\text { unknown } \\
\text { peers }\end{array}$} & $0=$ not give sweet & $42(17 \%)$ & $17(24 \%)$ & 59 & \multirow[t]{3}{*}{11.652} & \multirow[t]{3}{*}{0.003} \\
\hline & $1=$ give 1 sweet & $203(70,5 \%)$ & $55(76 \%)$ & 258 & & \\
\hline & $2=$ give 2 sweets & $35(12.5 \%)$ & $0(0 \%)$ & 35 & & \\
\hline
\end{tabular}

There were found no differences between studied groups in prosocial condition toward friends, as well as anonymous peers (see Table 3). The decisions of rural children in fairness (envy) game were more polarized, compared to urban children (see Table 3). On the one hand, 7 per cent of rural players did not give any sweet in the case of friends, and 9.3 per cent in the case of unknown child, while urban children did not select such option at all in any of these cases. Around 62 per cent of rural children preferred the fairness solution, both with 
friends and unknown opponent, while in the case of urban players such solution was chosen by 57 per cent with friends and 92 per cent with unknown partner. The distribution of sharing decision in rural and urban samples was different in general, as well, as within categories of friends and unknown partner in particular (see Table 3). While 14 per cent of rural players were ready to donate all sweets to their opponent, leaving nothing to themselves in sharing game with friends, 0 per cent of urban children selected this option. On the other hand, 12 per cent of rural children decided not to share sweets with friends at all, whereas only 4 per cent of urban children came to this decision. 74 per cent of rural children and 96 per cent of urban ones were ready to share sweets on equal bases $(1: 1)$ with friends. In the case of unknown partner sharing decisions of the rural and urban children differed significantly as well (see Table 3). 12.5 per cent of rural children were ready to give all sweets to unknown child, while in the urban sample - none. In rural sample 17 per cent of players decided not to share at all, and in urban sample - 24 per cent.

\section{Gender difference in decision-making}

We have also tested sex differences in decision-making (see Table 4). Sex differences were only significant in fairness game with friends, girls were more driven by fairness principles, and boys were more highly altruistic (38 per cent) compared to girls (27\%). In sharing game, no sex differences were registered in the case of playing with friends. Boys were more highly altruistic, compared to girls, playing with an unknown partner (14 per cent against 6 per cent). Meanwhile, girls were more mildly altruistic ( 82 per cent against 66 per cent among boys).

Table 4

Sex differences in prosocial, fairness and sharing games

\begin{tabular}{|c|c|c|c|c|c|c|}
\hline \multirow{2}{*}{ Games } & \multirow{2}{*}{$\begin{array}{c}\text { Condition } \\
\text { of games }\end{array}$} & \multicolumn{2}{|c|}{ Sex } & \multirow{2}{*}{ Total } & \multirow{2}{*}{$\begin{array}{c}\text { Chi } \\
\text { square }\end{array}$} & \multirow[b]{2}{*}{$\mathbf{p}$} \\
\hline & & Male & Female & & & \\
\hline \multirow{2}{*}{$\begin{array}{l}\text { Prosocial } \\
\text { game with } \\
\text { friend }\end{array}$} & $0=$ not give sweet & $10(5 \%)$ & $9(6 \%)$ & 19 & \multirow[t]{2}{*}{0.025} & \multirow[t]{2}{*}{0.874} \\
\hline & $1=$ give 1 sweet & $182(95 \%)$ & $152(94 \%)$ & 334 & & \\
\hline \multirow{2}{*}{$\begin{array}{l}\text { Prosocial } \\
\text { game with } \\
\text { unknown } \\
\text { peers }\end{array}$} & $0=$ not give sweet & $31(16 \%)$ & $24(15 \%)$ & 55 & \multirow[t]{2}{*}{0.116} & \multirow[t]{2}{*}{0.733} \\
\hline & $1=$ give 1 sweet & $160(84 \%)$ & $137(85 \%)$ & 297 & & \\
\hline
\end{tabular}


Table 4 (continued)

\begin{tabular}{|c|c|c|c|c|c|c|}
\hline \multirow{5}{*}{$\begin{array}{l}\text { Fairness } \\
\text { game with } \\
\text { friend }\end{array}$} & $0=$ not give sweet & $7(4 \%)$ & $12(8 \%)$ & 19 & \multirow[t]{5}{*}{6.437} & \multirow[t]{5}{*}{0.04} \\
\hline & $1=$ give 1 sweet & $111(58 \%)$ & $105(65 \%)$ & 216 & & \\
\hline & $2=$ give 2 sweets & $74(38 \%)$ & $44(27 \%)$ & 118 & & \\
\hline & $1=$ give 1 sweet & $126(66 \%)$ & $132(82 \%)$ & 258 & & \\
\hline & $2=$ give 2 sweets & $27(14 \%)$ & $9(6 \%)$ & 36 & & \\
\hline \multirow{3}{*}{$\begin{array}{l}\text { Fairness } \\
\text { game with } \\
\text { unknown } \\
\text { peers }\end{array}$} & $0=$ not give sweet & $12(6 \%)$ & $14(9 \%)$ & 26 & \multirow[t]{3}{*}{4.187} & \multirow[t]{3}{*}{0.123} \\
\hline & $1=$ give 1 sweet & $125(66 \%)$ & $116(72 \%)$ & 241 & & \\
\hline & $2=$ give 2 sweets & $54(28 \%)$ & $31(19 \%)$ & 85 & & \\
\hline \multirow{3}{*}{$\begin{array}{l}\text { Sharing } \\
\text { game with } \\
\text { friend }\end{array}$} & $0=$ not give sweet & $23(12 \%)$ & $14(9 \%)$ & 37 & \multirow[t]{3}{*}{1.969} & \multirow[t]{3}{*}{0.374} \\
\hline & $1=$ give 1 sweet & $151(79 \%)$ & $126(78 \%)$ & 277 & & \\
\hline & $2=$ give 2 sweets & $18(9 \%)$ & $21(13 \%)$ & 39 & & \\
\hline \multirow{3}{*}{$\begin{array}{l}\text { Sharing } \\
\text { game with } \\
\text { unknown } \\
\text { peers }\end{array}$} & $0=$ not give sweet & $39(20 \%)$ & $20(12 \%)$ & 59 & \multirow[t]{3}{*}{12.046} & \multirow[t]{3}{*}{0.002} \\
\hline & $1=$ give 1 sweet & $126(66 \%)$ & $132(82 \%)$ & 258 & & \\
\hline & $2=$ give 2 sweets & $27(14 \%)$ & $9(6 \%)$ & 36 & & \\
\hline
\end{tabular}

\section{The behavioral types of decision makers}

Using the procedure described in the section 'Experimental Design and Procedure', we organized the players on the basis of results obtained for all three games into differentiated behavioral types (see Table 5).

Table 5

Percentage of occurrence of behavioral types of decision makers, based on allocations in all three games, played with friends and unknown partners, in total and separately for different age categories of players

\begin{tabular}{|c|c|c|c|c|c|c|c|c|}
\hline \multirow[b]{2}{*}{$\begin{array}{c}\text { Beha- } \\
\text { vioral types }\end{array}$} & \multirow[b]{2}{*}{$\begin{array}{c}\text { Friends } \\
\text { (total) } \\
(\%)\end{array}$} & \multirow{2}{*}{$\begin{array}{c}\text { Anony- } \\
\text { mous } \\
\text { (total) } \\
(\%)\end{array}$} & \multicolumn{2}{|c|}{ Age 1 (12-13) } & \multicolumn{2}{|c|}{ Age 2 (14-15) } & \multicolumn{2}{|c|}{ Age 3 (16-20) } \\
\hline & & & $\begin{array}{c}\text { Friends } \\
(\%)\end{array}$ & $\begin{array}{c}\text { Anony- } \\
\text { mous } \\
(\%)\end{array}$ & $\begin{array}{c}\text { Friends } \\
(\%)\end{array}$ & $\begin{array}{c}\text { Anony- } \\
\text { mous } \\
(\%)\end{array}$ & $\begin{array}{c}\text { Friends } \\
(\%)\end{array}$ & $\begin{array}{c}\text { Anony- } \\
\text { mous } \\
(\%)\end{array}$ \\
\hline \begin{tabular}{|l|}
$\begin{array}{l}\text { Highly } \\
\text { egalitarian }\end{array}$ \\
\end{tabular} & 48.9 & 50.3 & 54.3 & 48.6 & 50.5 & 49.5 & 43.5 & 49.6 \\
\hline \begin{tabular}{|l|} 
Weakly \\
egalitarian
\end{tabular} & 4.0 & 4.0 & 0 & 5.7 & 3.8 & 4.4 & 6.1 & 2.6 \\
\hline \begin{tabular}{|l|} 
Highly \\
altruistic
\end{tabular} & 3.7 & 4.8 & 0 & 0 & 4.3 & 5.4 & 4.3 & 6.1 \\
\hline $\begin{array}{l}\text { Medium } \\
\text { altruistic }\end{array}$ & 24.7 & 14.2 & 34.3 & 20.0 & 25.5 & 13.0 & 18.3 & 12.2 \\
\hline
\end{tabular}


Table 5 (continued)

\begin{tabular}{|c|c|c|c|c|c|c|c|c|}
\hline \multirow[b]{2}{*}{$\begin{array}{c}\text { Beha- } \\
\text { vioral types }\end{array}$} & \multirow[b]{2}{*}{$\begin{array}{c}\text { Friends } \\
\text { (total) } \\
\text { (\%) }\end{array}$} & \multirow{2}{*}{$\begin{array}{c}\text { Anony- } \\
\text { mous } \\
\text { (total) } \\
(\%)\end{array}$} & \multicolumn{2}{|c|}{ Age 1 (12-13) } & \multicolumn{2}{|c|}{ Age 2 (14-15) } & \multicolumn{2}{|c|}{ Age 3 (16-20) } \\
\hline & & & $\begin{array}{c}\text { Friends } \\
\text { (\%) }\end{array}$ & $\begin{array}{c}\text { Anony- } \\
\text { mous } \\
(\%)\end{array}$ & $\begin{array}{c}\text { Friends } \\
(\%)\end{array}$ & $\begin{array}{c}\text { Anony- } \\
\text { mous } \\
(\%)\end{array}$ & $\begin{array}{c}\text { Friends } \\
(\%)\end{array}$ & $\begin{array}{c}\text { Anony- } \\
\text { mous } \\
(\%)\end{array}$ \\
\hline $\begin{array}{l}\text { Weakly } \\
\text { altruistic }\end{array}$ & 3.7 & 2.8 & 2.9 & 2.9 & 4.3 & 3.3 & 2.6 & 2.6 \\
\hline $\begin{array}{l}\text { Highly } \\
\text { spiteful }\end{array}$ & 0.9 & 0.9 & 0 & 2.9 & 0.5 & 0.5 & 1.8 & 0.9 \\
\hline $\begin{array}{l}\text { Weakly } \\
\text { spiteful }\end{array}$ & 0.6 & 1.7 & 2.9 & 2.9 & 0.5 & 2.2 & 0 & 0.9 \\
\hline $\begin{array}{l}\text { Mixed } \\
\text { strategies }\end{array}$ & 13.5 & 21.3 & 5.6 & 17.0 & 10.6 & 21.7 & 23.4 & 25.1 \\
\hline
\end{tabular}

In total sample the main differences in decisions towards friends and anonymous partners concerned the mild altruistic strategy: it was practiced more frequently towards friends. These differences were observed in all age categories. After rearrangement of the behavioral types into three general categories (egalitarian, altruistic and spiteful), the trend remained the same: more players were altruistic towards friends than towards unknown partners (see Table 6). The percentage of players, practicing egalitarian and spiteful strategies towards friends and unknown partner was similar.

Table 6

Percentage of occurrence of three generalized behavioral types of decision makers, based on allocations in all three games, played with friends and unknown partners, in total and separately for different age categories of players

\begin{tabular}{|c|c|c|c|c|c|c|c|c|}
\hline \multirow[b]{2}{*}{$\begin{array}{c}\text { Behav- } \\
\text { ioral } \\
\text { types }\end{array}$} & \multirow[b]{2}{*}{$\mid \begin{array}{c}\text { Friends } \\
\text { (total) } \\
(\%)\end{array}$} & \multirow{2}{*}{$\begin{array}{c}\text { Anony- } \\
\text { mous } \\
\text { (total) } \\
(\%)\end{array}$} & \multicolumn{2}{|c|}{ Age $1(12-13)$} & \multicolumn{2}{|c|}{ Age 2 (14-15) } & \multicolumn{2}{|c|}{ Age 3 (16-20) } \\
\hline & & & $\begin{array}{c}\text { Friends } \\
(\%)\end{array}$ & $\begin{array}{c}\text { Anon- } \\
\text { ymous } \\
(\%)\end{array}$ & $\begin{array}{c}\text { Friends } \\
(\%)\end{array}$ & $\begin{array}{c}\text { Anon- } \\
\text { ymous } \\
(\%)\end{array}$ & $\begin{array}{c}\text { Friends } \\
(\%)\end{array}$ & $\begin{array}{c}\text { Anon- } \\
\text { ymous } \\
(\%)\end{array}$ \\
\hline $\begin{array}{l}\text { Egalitar- } \\
\text { ian }\end{array}$ & 52.9 & 54.3 & 54.3 & 54.3 & 54.3 & 53.9 & 49.6 & 52.2 \\
\hline $\begin{array}{l}\text { Altruis- } \\
\text { tic }\end{array}$ & 32.1 & 21.8 & 37.2 & 22.9 & 34.1 & 21.3 & 25.2 & 20.9 \\
\hline Spiteful & 1.5 & 2.6 & 2.9 & 5.8 & 1.0 & 2.7 & 1.8 & 1.8 \\
\hline $\begin{array}{l}\text { Mixed } \\
\text { strate- } \\
\text { gies }\end{array}$ & 13.5 & 21.3 & 5.6 & 17.0 & 10.6 & 21.7 & 23.4 & 25.1 \\
\hline
\end{tabular}




\section{DISCUSSION}

Our data demonstrated that friendship (group membership) has been a significant factor in costly resource allocation decision-making among African children and adolescents. This was true for all the three games, including prosocial decision-making, as well as more altruistic choices in fairness and sharing games. Importantly, in the case of most costly decisions (donation of two sweets out of two to the opponent in sharing game) friends were obviously treated better than unknown partners. We conclude that friendship plays important simulative role in the development of prosocial and altruistic behavior during adolescence. Earlier Güroglu with co-authors came to identical conclusions, based on different experimental design, applied to Western sample of children with the age range between 9 and 18 years (Güroglu et al. 2014). Thus, taken together both these studies, we may conclude that preferable altruistic behavior towards friends during adolescence may be universal feature of human social behavior, present both in traditional and industrial societies.

One should emphasize that in evolutionary perspective, friendship may solve as an important extension of kinship, and such extension became especially beneficial in the context of group competition. Given the fact that small-scale societies prevailed in human history, altruism towards friends must have been positively selected.

The parochial effect has been demonstrated in our study for the whole sample (all the three types of games included), and became more obviously expressed with age, reaching maximum at the age of $14-15$ years. Given that the period of $14-15$ years is the most common age for initiations in traditional societies, when boys are expected to join their age-class groups and spend some time (before marriage) dwelling together, the pattern found in our study may be positively selected as well. Thus, our first hypothesis has been confirmed. Importantly, rural participants demonstrated a higher level of parochialism, compared to the urban ones. This is not by changes as well, given that in small-scale societies the adolescents of similar age have higher probability to contact with each other, and to be dependent of each other during the time of social and ecological famines. Hence, our second hypothesis is also confirmed. In case of more personalized social environment and kin-ethnic oriented social network, parochialism was more expressed. 
In our study, rural children demonstrated greater variability in sharing decision-making compared to urban ones, and higher altruistic allocations both towards friends and anonymous child were more frequent, compared to urban ones. The level of mild altruism was higher among urban environment in the case of friends, and higher among rural children in the case of anonymous child. The fact that rural children demonstrated higher level of altruism, both towards friends and an unknown child, compared to urban ones may be interpreted in the light of differences between urban and rural social environment. In rural environment with mono-ethnic population (Wameru in our case), potentially all peers are same-group members with a relatively high level of genetic relatedness. Thus, the rural children may treat an 'anonymous child' as a potential member of the same community, while for urban children they are aliens.

The evolutionary theory of parochial altruism suggests that altruism and parochialism evolved simultaneously (co-evolved) being an adaptation to frequent intergroup aggression (Choi and Bowles 2007). And since it is males who are mostly involved in group conflicts, the evolution has generated the gender differences in parochialism. Males may benefit more from parochial altruism than females, and if this hypothesis is correct, boys are expected to demonstrate more readiness for higher altruism towards friends in all three games. And, indeed, we found that boys were more parochial, compared to girls, particularly this was obvious in the sharing game. Hence, our fourth hypothesis has been confirmed as well, and our results provide another confirmation of the parochial altruism hypothesis.

Around 50 per cent of players in our study were oriented at egalitarianism in their decisions, demonstrating that desire for equal distribution of limited resources may be basic for human societies. The 1213 year-old African children from rural and urban communities were obviously capable to take the 'other-orientation' perspectives and incorporate this perspective into their decision-making. We demonstrate the influence of social environment on decisions to share, to behave in egalitarian manner, or to spike. Urban children have been more motivated by egalitarian principles in decision-making concerning anonymous peers in envy (fairness) game, compared to rural children. Hence, our third hypothesis has been confirmed as well. These findings may reflect the basic principle of equal distribution of public goods in massanonymous society with low level of genetic relatedness. 
Our data revealed that human behavior becomes less egoistic with age, which may be determined by the acquisition of cultural social norms and prescriptions in collectivistic societies. One can hardly doubt that egalitarianism had shaped many small-scale societies (Boehm et al. 1993; Boehm 1997). Some findings even suggested that such behavior may have certain genetic bases (Wallace 2007).

The fifth hypothesis has been partly confirmed. For females we demonstrated a significant positive association between intentions to help relatives and altruistic decision-making towards friends, but failed to find a similar tendency for males. Contrary to our expectations, the positive association between helping relatives and altruism towards unknown peers was demonstrated for males. These results contradict our main findings about the gender differences for parochial decisionmaking and need further studies. However, this may be explained by the rural children's peculiar perception of anonymous child as a member of the same community. Our data suggest that urban children are more discriminant in their allocations, and friendship may play the role of a relational modality, affecting their interactions, as demonstrated earlier by other scholars (Kathiravelu and Bunnell 2018).

Finally, we have demonstrated that the number of players who take egoistic and spiteful decisions decreases with age. This may indicate the growing pressure of normative roles acquired with age (Fehr et al. 2008). The increasing percentage of mixed decisions in allocations with age may also indicate the further development of perspectivetaking abilities, given that with age the individuals begin to be more worried about their own public image, and become more sensitive of what others think about them (Wellman et al. 2001). At an older age they take care of how their behavior is embedded in generally accepted norms and what benefit or harm it may entail (Eisenberg and Mussen 1989; Choi and Bowles 2007; Fehr et al. 2008). The recent review of the explanations for the gap between children's beliefs about equal distribution of resources and real allocations in the dictator game suggests a complex nature, including self-regulation, social distance, and social learning (Blake 2018). The 'other-orientation' is tapped by the cognitive ability to take others' perspectives and incorporate this perspective into decision-making which continues to develop into late adolescence (Dumontheil et al. 2010).

Of course, the results, obtained in this study have certain limitations. First of all, we used sweets as 'currency' in our study, while 
they may be of different value for younger and older participants, thus influencing their choices. Besides, sweets may be of different value for rural and urban players. Gender differences obtained in our study referred to children and adolescents, while among the adults the results may be different, given the exogamy principles of marriage and patrilocality. Besides, along with the three main behavioral strategies (egalitarian, altruistic and spiteful) a substantial percentage of mixed strategies (mentioned as others' in tables and figures) were registered, and the number of players, following such strategies tend to increase with age. This may be due to the increasing pressure of social norms with age which block the individuals' primary motivations of decisionmaking. It is also important to consider this category in future studies.

\section{ACKNOWLEDGEMENTS}

This study has been supported by the Russian Science Foundation (project № 18-18-00075). The data collection was approved by the Commission for Science and Technology of Tanzania. We thank the Russian Centre for Science and Culture in Dar-es-Salaam for constant support and valuable assistance during our research work in Tanzania, and our respondents for their cooperation and tolerance.

\section{REFERENCES}

Balliet, D., Wu, J., and De Dreu, C. K. 2014. In-group Favoritism in Cooperation: A Meta-Analysis. Psychological Bulletin 140 (6): 1556.

Ben-Ner, A., McCall, B. P., Stephane, M., and Wang, H. 2009. Identity and In-group/Out-group Differentiation in Work and Giving Behaviors: Experimental Evidence. Journal of Economic Behavior and Organization 72 (1): 153-170.

Bernhard, H., Fischbacher, U., and Fehr, E. 2006. Parochial Altruism in $\mathrm{Hu}-$ mans. Nature 442 (7105): 912.

Blake, P. R. 2018. Giving What One Should: Explanations for the Knowledge-Behavior Gap for Altruistic Giving. Current Opinion in Psychology 20: 1-5.

Boehm, C., Barclay, H. B., Dentan, R. K., Dupre, M. C., Hill, J. D., Kent, S., ... and Rayner, S. 1993. Egalitarian Behavior and Reverse Dominance Hierarchy [And Comments and Reply]. Current Anthropology 34 (3): 227-254.

Boehm, C. 1997. Impact of the Human Egalitarian Syndrome on Darwinian Selection Mechanics. The American Naturalist 150 (S1): S100-S121. 
Bornstein, G. 2003. Intergroup Conflict: Individual, Group, and Collective Interests. Personality and Social Psychology Review 7 (2): 129-145.

Boyd, R., Gintis, H., Bowles, S., and Richerson, P. J. 2003. The Evolution of Altruistic Punishment. Proceedings of the National Academy of Sciences100 (6): 3531-3535.

Brañas-Garza, P., Durán, M. A., and Espinosa, M. P. 2012. Favouring Friends. Bulletin of Economic Research 64 (2): 172-178.

Butovskaya, M. L., Burkova, V. N., and Karelin, D. V. 2016. The Wameru of Tanzania: Historical Origin and Their Role in the Process of National Integration. Social Evolution and History 15 (2): 141-163.

Carlo, G., Fabes, R. A., Laible, D., and Kupanoff, K. 1999. Early Adolescence and Prosocial/Moral Behavior II: The Role of Social and Contextual Influences. The Journal of Early Adolescence 19 (2): 133-147. Doi:10.1177/ 0272431699019002001.

Chagnon, N. A. 1988. Life Histories, Blood Revenge, and Warfare in a Tribal Population. Science 239 (4843): 985-992.

Charness, G., and Rabin, M. 2002. Understanding Social Preferences with Simple Tests. The Quarterly Journal of Economics 117 (3): 817-869.

Choi, J. K., and Bowles, S. 2007. The Coevolution of Parochial Altruism and War. Science 318 (5850): 636-640.

Croson, R., and Gneezy, U. 2009. Gender Differences in Preferences. Journal of Economic Literature 47 (2): 448-474.

Dawes, C. T., Fowler, J. H., Johnson, T., McElreath, R., and Smirnov, O. 2007. Egalitarian Motives in Humans. Nature 446 (7137): 794.

Dumontheil, I., Apperly, I. A., and Blakemore, S. J. 2010. Online Usage of Theory of Mind Continues to Develop in Late Adolescence. Developmental Science 13 (2): 331-338. Doi: 10.1111/j.1467-7687.2009.00888.x.

Elster, J. 1989. The Cement of Society: A Survey of Social Order. Cambridge University Press.

Eisenberg, N., and Mussen, P. H. 1989. The Roots of Prosocial Behavior in Children. Cambridge University Press.

Fehr, E., and Gächter, S. 2002. Altruistic Punishment in Humans. Nature 415 (6868): 137.

Fehr, E., Bernhard, H., and Rockenbach, B. 2008. Egalitarianism in Young Children. Nature 454 (7208): 1079. Doi:10.1038/nature07155.

Fehr, E., Glätzle-Rützler, D., and Sutter, M. 2013. The Development of Egalitarianism, Altruism, Spite and Parochialism in Childhood and Adolescence. European Economic Review 64: 369-383. Doi:10.1016/j.euroecorev2013. 09.006. 
Fehr, E., and Schmidt, K. M. 1999. A Theory of Fairness, Competition, and Cooperation. The Quarterly Journal of Economics 114 (3): 817-868.

Fowler, J. H., Johnson, T., and Smirnov, O. 2005. Human Behaviour: Egalitarian Motive and Altruistic Punishment. Nature 433 (7021): E1.

Gintis, H. 2000. Strong Reciprocity and Human Sociality (No. 2000-02). Working Paper, University of Massachusetts, Department of Economics.

Güroğlu, B., Will, G. J., and Crone, E. A. 2014. Neural Correlates of Advantageous and Disadvantageous Inequity in Sharing Decisions. PloS One 9 (9): e107996.

Hartup, W. W. 1996. The Company They Keep: Friendships and Their Developmental Significance. Child Development 67 (1): 1-13.

Kaplan, H., Gurven, M., Hill, K., and Hurtado, A. M. 2005. The Natural History of Human Food Sharing and Cooperation: A Review and a New Multi-Individual Approach to the Negotiation of Norms. Moral Sentiments and Material Interests: The Foundations of Cooperation in Economic Life 6: 75-113.

Kathiravelu, L., and Bunnell, T. 2018. Introduction: Urban Friendship Networks: Affective Negotiations and Potentialities of Care. Urban Studies 55 (3): 491-504.

Lei, V., and Vesely, F. 2010. In-Group versus Out-Group Trust: The Impact of Income Inequality. Southern Economic Journal 76 (4): 1049-1063. Doi: 10.4284/sej.2010.76.4.1049.

Liebe, U., and Tutic, A. 2010. Status Groups and Altruistic Behaviour in Dictator Games. Rationality and Society 22 (3): 353-380.

Lerner, G. 1986. The Creation of Patriarchy. Vol. 1. Oxford University Press.

Liebe, U., and Tutic, A. 2010. Status Groups and Altruistic Behaviour in Dictator Games. Rationality and Society 22 (3): 353-380. Doi: 10.1177/ 1043463110366232.

Moore, C., Barresi, J., and Thompson, C. 1998. The Cognitive Basis of Future-Oriented Prosocial Behavior. Social Development 7 (2): 198-218. Doi: 10.1111/1467-9507.00062.

Nowak, M. A., and Sigmund, K. 2005. Evolution of Indirect Reciprocity. Nature 437 (7063): 1291.

Sober, E., and Wilson, D. S. 1998. Unto Others: The Evolution and Psychology of Unselfish Behavior (No. 218). Harvard University Press.

Stürmer, S., Snyder, M., and Omoto, A. M. 2005. Prosocial Emotions and Helping: The Moderating Role of Group Membership. Journal of Personality and Social Psychology 88 (3): 532. Doi:10.1037/0022-3514.88. 3.532 . 
Tajfel, H., Billig, M. G., Bundy, R. P., and Flament, C. 1971. Social Categorization and Intergroup Behaviour. European Journal of Social Psychology 1 (2): 149-178.

Wallace, J. L. 2007. Building a Better Aspirin: Gaseous Solutions to a Century-Old Problem. British Journal of Pharmacology 152 (4): 421-428.

Wellman, H. M., Cross, D., and Watson, J. 2001. Meta-Analysis of Theory-Of-Mind Development: The Truth about False Belief. Child Development 72 (3): 655-684.

Whitt, S., and Wilson, R. K. 2007. The Dictator Game, Fairness and Ethnicity in Postwar Bosnia. American Journal of Political Science 51 (3): 655668. Doi:10.1111/j.1540-5907.2007.00273.x. 